\title{
Retraction Note: LAMP2 expression dictates azacytidine response and prognosis in MDS/AML
}

\author{
Alix Dubois · Nathan Furstoss · Anne Calleja - Marwa Zerhouni - Thomas Cluzeau • Coline Savy • \\ Sandrine Marchetti - Mohamed Amine Hamouda - Sonia Boulakirba · François Orange - Sandra Lacas-Gervais • \\ Jean-Michel Karsenti • Nicolas Mounier • Jérôme Tamburini · Alexandre Puissant · Frederic Luciano • \\ Arnaud Jacquel · Patrick Auberger · Guillaume Robert
}

Published online: 14 July 2020

(c) The Author(s) 2020. This article is published with open access

Retraction to: Leukemia

https://doi.org/10.1038/s41375-018-0336-1

The authors have decided to retract this article [1] because after publication they discovered that the SKM1-R, OCI-AML2 and MOLM13 cell lines used were crosscontaminated with murine hematopoietic cells. The results obtained using these cell lines are therefore unreliable. The data presented on primary patient samples remains valid.

All authors agree with this retraction.

Open Access This article is licensed under a Creative Commons Attribution 4.0 International License, which permits use, sharing, adaptation, distribution and reproduction in any medium or format, as long as you give appropriate credit to the original author(s) and the source, provide a link to the Creative Commons license, and indicate if changes were made. The images or other third party material in this article are included in the article's Creative Commons license, unless indicated otherwise in a credit line to the material. If material is not included in the article's Creative Commons license and your intended use is not permitted by statutory regulation or exceeds the permitted use, you will need to obtain permission directly from the copyright holder. To view a copy of this license, visit http://creativecommons. org/licenses/by/4.0/.

\section{References}

1. Dubois A, Furstoss N, Calleja A, Zerhouni M, Cluzeau T, Savy C et al. LAMP2 expression dictates azacytidine response and prognosis in MDS/AML. Leukemia. 2019;33:1501-13. 